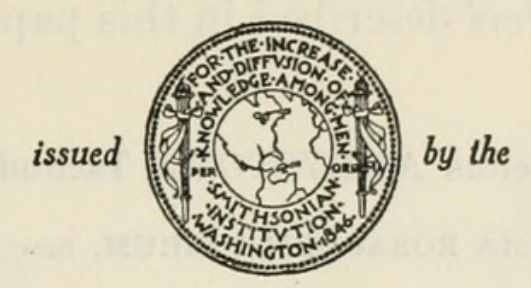

SMITHSONIAN INSTITUTION

U. S. NATIONAL MUSEUM

\title{
NOTES ON A HERPETOLOGICAL COLLECTION FROM OAXACA AND OTHER LOCALITIES IN MEXICO
}

\section{By Frederick A. Shannon}

DURING the summer of 1946, Walter S. Miller, of the Summer Institute of Linguistics, Mexico City, made a herpetological collection in the vicinity of San Lucas Camotlán, Oaxaca, where he was engaged in making a philological study of the Mixes Indians. The collection would be to the credit of a professional herpetologist, for not only is it well labeled as to time, date, and place, but it contains careful notes on habits, color in life, habitat, and other pertinent data. Notes on this material constitute the bulk of this paper, which is a Contribution from the University of Illinois Museum of Natural History. In addition, other miscellaneous specimens that have come to my attention during this study and material that represents helpful contributions to the study of Mexican herpetology have been included. Most of the specimens are in the collection of the United States National Museum.

Quotations without label are Mr. Miller's. In the main they are unaltered, but I have made occasional slight changes that better express the meaning of Mr. Miller's original field notes.

My sincere thanks are due Dr. Hobart M. Smith and W. Leslie Burger, both of the University of Illinois-to Dr. Smith for many helpful suggestions made during the course of this study, and to $\mathrm{Mr}$. Burger for identifying the Bothrops, a discussion of which is published elsewhere. My thanks are also due my wife, Ellen Jordan Shannon, who illustrated the paper. I also thank Dr. Doris M. Cochran, of the United States National Museum staff, through whom arrangements 
were made for the University of Illinois to retain one of the two paratypes of Hyla milleri described in this paper, and for permission to study the material.

\section{Genus AMBYSTOMA Tschudi}

\section{AMBystoma ROSACEUM NIGRUM, new subspecies}

FIgURe 91

Holotype-U.S.N.M. No. 123581, larva; collected by Ralph G. Miller on an indeterminate date.

\section{Type locality.-El Salto, Durango.}

Diagnosis.-A large neotenic salamander characterized by a black ground color with yellow markings; by the presence of black ventral bands; by a short leg (toes of extended leg do not closely approach adpressed elbow); and by a pedal phalangeal formula of 2-2-3-3-2.

Description.-Dorsal fin originating on back ( $23 \mathrm{~mm}$. from snout), at same level as point of origin of anterior limbs; fin elevated $3.5 \mathrm{~mm}$. at level of hind limbs, and $4.5 \mathrm{~mm}$. at base of tail; gill rakers on middle arch 22 in number. Vomerine teeth in curved patches separated by a distance less than a third their lengths, about 33 in number and as many as 4 in a transverse row ; 34 maxillary-premaxillary teeth; 48-52 splenial teeth, arranged in two rows posteriorly; 10 pterygoid teeth; 11 costal grooves not counting slight auxiliary grooves over axilla and groin; phalangeal formula of hand 2-2-3-2, of foot $2-2-3-3-2$; webbing not reaching distal ends of metacarpals or metatarsals (i. e., base of digits includes terminal portions of metacarpals) ; at least 5-mm. space between adpressed leg and elbow.

The light ground color of Taylor's (1941) specimens of rosaceum is so largely replaced by black markings that an actual reversal of color pattern is apparent, nigrum showing a black ground color with yellow (in alcohol) markings. The top of the head is black with indistinct light reticulations; yellow on body limited to indistinct longitudinal bands, which tend to break up into spots; tail mottled with widely separated, irregularly shaped light blotches; caudal fins translucent and heavily mottled with black; limbs yellow-mottled; belly yellow, marked by two long, wide lateral bands of black which are separated from black of sides by broken lateroventral yellow bands.

Measurements of holotype in millimeters.-Total length 110 ; body length 59 ; tail length 51 ; length of snout 5 ; eye width 3 ; snout to arm insertion 19.

Remarks.-Although no intergradation area has been demonstrated between nigrum and the more northern rosaceum, nigrum is here interpreted as being of subspecific rank. The pattern type is essentially 

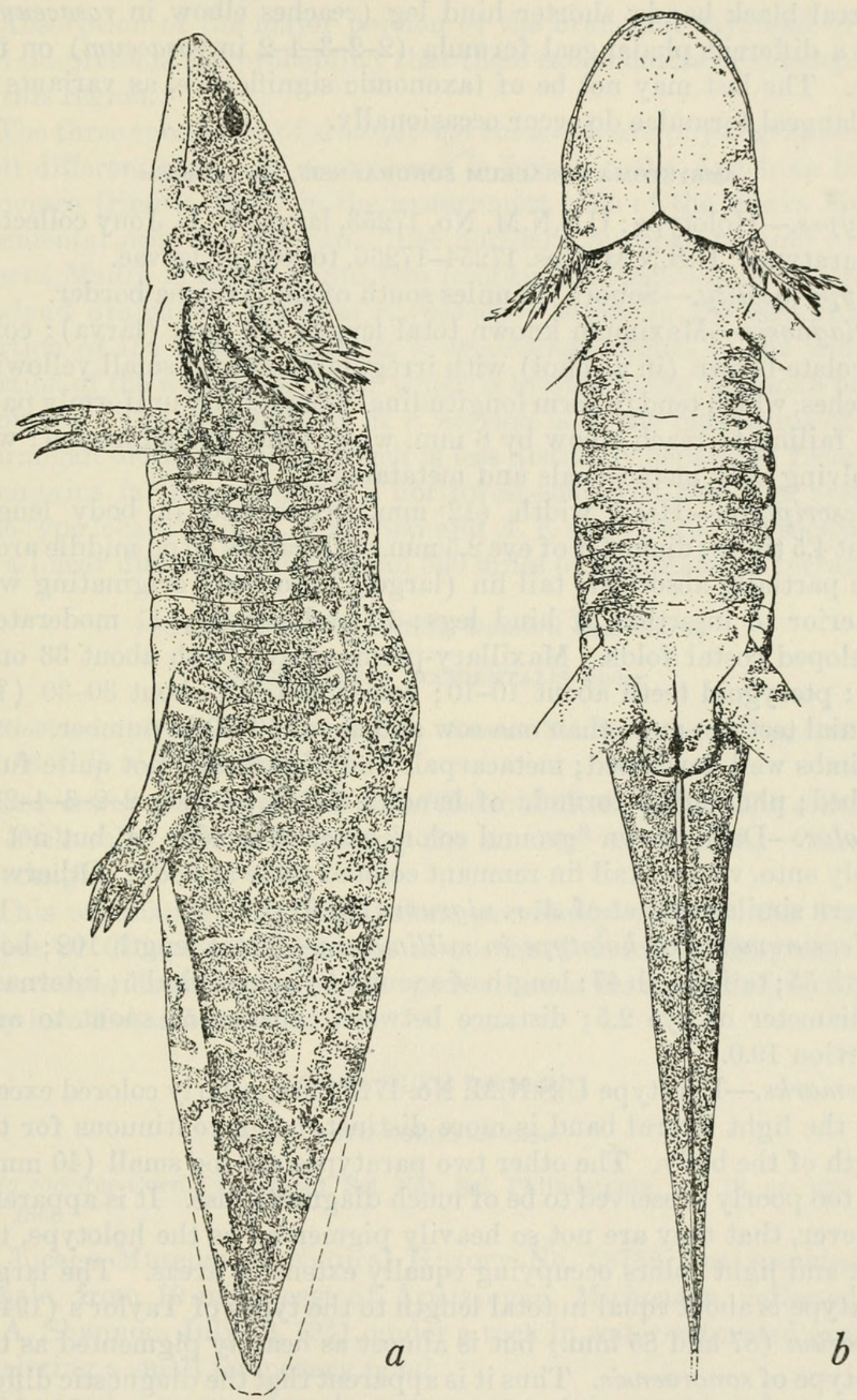

Figure 91.-Ambystoma rosaceum nigrum, new subspecies, holotype, $\times 1.5$. 
the same in both, except for the above-mentioned reversal. Other differentiating characters found in nigrum but not in rosaceum are ventral black bands, shorter hind leg (reaches elbow in rosaceum), and a different phalangeal formula $(2-2-3-4-2$ in rosaceum $)$ on the foot. The last may not be of taxonomic significance, as variants in phalangeal formulae do occur occasionally.

\section{AMBYSTOMA ROSACEUM SONORAENSIS, new subspecies}

Types.-Holotype: U.S.N.M. No. 17253, larva ; P. L. Jouy collector. Paratypes: U.S.N.M. Nos. 17254-17256, topotypic larvae.

Type locality.-Sonora, 32 miles south of the Arizona border.

Diagnosis.-Maximum known total length $102 \mathrm{~mm}$. (larva); color chocolate-brown (in alcohol) with irregularly shaped small yellowish blotches, which tend to form longitudinal bands; belly uniformly pale; toes failing to reach elbow by $6 \mathrm{~mm}$. when limbs are adpressed; web involving only metacarpals and metatarsals.

Description.-Head width (12 mm.) contained in body length about 4.5 times; diameter of eye $2.5 \mathrm{~mm}$.; gill rakers 20 on middle arch; gills partially absorbed; tail fin (largely absorbed) originating well posterior to insertion of hind legs; 10 and possibly 11 moderately developed costal folds. Maxillary-premaxillary teeth about 33 on a side; pterygoid teeth about 10-10; vomerine teeth about $30-30$ (?); splenial teeth in more than one row and about 50-50 in number.

Limbs well developed; metacarpals and metatarsals not quite fully webbed; phalangeal formula of hand, 2-2-3-2, of foot, 2-2-3-4-2.

Color.-Dark brown "ground color" extends to edge of, but not or barely onto, venter; tail fin remnant colored same as body. Otherwise pattern similar to that of $A$.r. nigrum (fig. 91).

Measurements of holotype in millimeters.-Total length 102; body length 55 ; tail length 47 ; length of snout 4.5 ; interorbital 5 ; internasal 5 ; diameter of eye 2.5 ; distance between choanae 5 ; snout to arm insertion 19.0.

Remarks.-Paratype U.S.N.M. No. 17254 is similarly colored except that the light lateral band is more distinct, being continuous for the length of the body. The other two paratypes are too small $(40 \mathrm{~mm}$.) and too poorly preserved to be of much diagnostic use. It is apparent, however, that they are not so heavily pigmented as the holotype, the dark and light colors occupying equally extensive areas. The larger paratype is about equal in total length to the types of Taylor's (1941) rosaceum ( 87 and $85 \mathrm{~mm}$.) but is almost as heavily pigmented as the holotype of sonoraensis. Thus it is apparent that the diagnostic differences in coloration between $r$. rosaceum and $r$. sonoraensis are not age differences. A.r. sonoraensis is easily differentiated from nigrum by occurrence in the latter of ventral black bands. The lesser phalangeal 
formula of nigrum will be of doubtful significance until further specimens come to light.

Absorption of the major portion of the branchial rays and of the tail fin presents the probability that these salamanders metamorphose in this region.

The three subspecies of Ambystoma rosaceum are physiographically well differentiated. A. r. rosaceum is found in the Apachian biotic province (Smith, 1939) in the easternmost hills of the Sierra Madre Occidental near the Plateau. The northern Mexican portion of the Sierra Madre is divided into two longitudinal sections by a central lowland drainage. Whereas $r$. rosaceum occurs in the easternmost portion of the eastern division, $r$. sonoraensis occurs in the western portion of the western division, which is located in the Arizonan biotic province. The type locality of $r$. nigrum is in the mountains of the Durangan biotic province, which is less distinctly separated from the mountains farther north by a northwest-southeast drainage system. The type localities of $A . r$. nigrum and A.r. sonoraensis are separated by a linear distance of more than 500 miles of mountainous terrain.

\section{Genus BOLITOGLOSSA Duméril and Bibron}

\section{BOLITOGLOSSA OCCIDENTALIS Taylor}

Bolitoglossa occidentalis TaYlon, Univ. Kansas Sci. Bull., vol. 27, pp. 145-147, fig. 1, C, pl. 9, figs. 1-4, 1941.

University of Illinois Museum of Natural History No. 3200, collected at Pichucalco, Chiapas, during the summer of 1937, by Clarence Goodnight.

This salamander has been taken previously only on the Pacific slopes of Chiapas. Pichucalco is on the Tabasco border, and this record extends the range of the species across the state, and undoubtedly into Tabasco.

\section{Genus BUFO Laurenti}

\section{BUFO COCCIFER Cope}

Bufo coccifer Cope, Proc. Acad. Sci. Nat. Sci. Philadelphia, vol. 18, pp. 130, 131, 1866.

Chicago Museum of Natural History No. 38756, one specimen, a female, from 10 miles east of Apatzingan, Michoacán, collected by F. A. Shannon, July 22, 1941, under a rock in water-saturated ground bordering a small temporary pond.

The toad, a mature female, represents a state record and a considerable eastward extension of the range of the species. Additional specimens will probably lead to a disclosure of subspecific differences, at least of color. 


\section{BUFO CRISTATUS Wiegmann}

Bufo cristatus Wiegmann, Isis von Oken, vol. 26 , pp. $660,661,1833$.

U.S.N.M. No. 123691, from San Lucas Camotlán, Oaxaca. This specimen constitutes a state record. It is somewhat large $(78 \mathrm{~mm}$.) for the species, although quite normal in appearance.

"Toad-caught in patio just after a rain when it came into the light of the gasoline lantern in front of the doorway about $9 \mathrm{p} . \mathrm{m}$. The Mixe name for it is nooch, which is applied to all toads."

\section{Genus ELEUTHERODACTYLUS Duméril and Bibron}

\section{ELEUTHERODACTYLUS NATATOR Taylor}

Eleutherodactylus natator TAYLoR, Univ. Kansas Sci. Bull., vol. 25, 1938, pp. 394 397 , pl. 39, fig. 2 ; pl. 40, 1939.

U.S.N.M. No. 123686, collected at San Lucas Camotlán, Oaxaca, in the river near the east edge of town at $8: 30$ p. m.; U.S.N.M. Nos. 123687 and 123688, taken on the edge of the river at 9 p. m. on April 29, 1946; U.S.N.M. No. 123698, caught in the river in the village at 9 p. m., May 7, 1946.

All specimens check well with Taylor's (1939) description and with specimens in the museum of the University of Illinois. They vary in length from 55 to $67 \mathrm{~mm}$.

Miller writes that specimen No. 123686 was brown dorsally with pink on sides and anterior surfaces of hind legs.

\section{Genus SYRRHOPHUS Cope}

\section{SYRRHOPHUS CYSTIGNATHOIDES (Cope)}

Phyllobatus cystignathoides Cope, Proc. Amer. Philos. Soc., vol. 17, pp. 89, 90, 1877.

Syrrhophus cystignathoides, NiEden, Das Tierreich, Lief. 46, pp. 399-401, 1923.

University of Illinois Museum of Natural History No. 3199, collected at Tamazunchale, San Luis Potosí, July 19, 1737, by Ottys Sanders. This specimen definitely establishes the presence of $S$. cystignathoides in San Luis Potosí. The specimen is extremely darkened, probably by preservative, the venter being nearly black. In other respects it fits cystignathoides.

\section{Genus HYLA Laurenti}

HYLA BISTINCTA LABECULATA, new subspecies

Figures $92, a ; 93, d$

Holotype.-U.S.N.M. No. 123689.

Type locality.-San Lucas Camotlán, Oaxaca. 

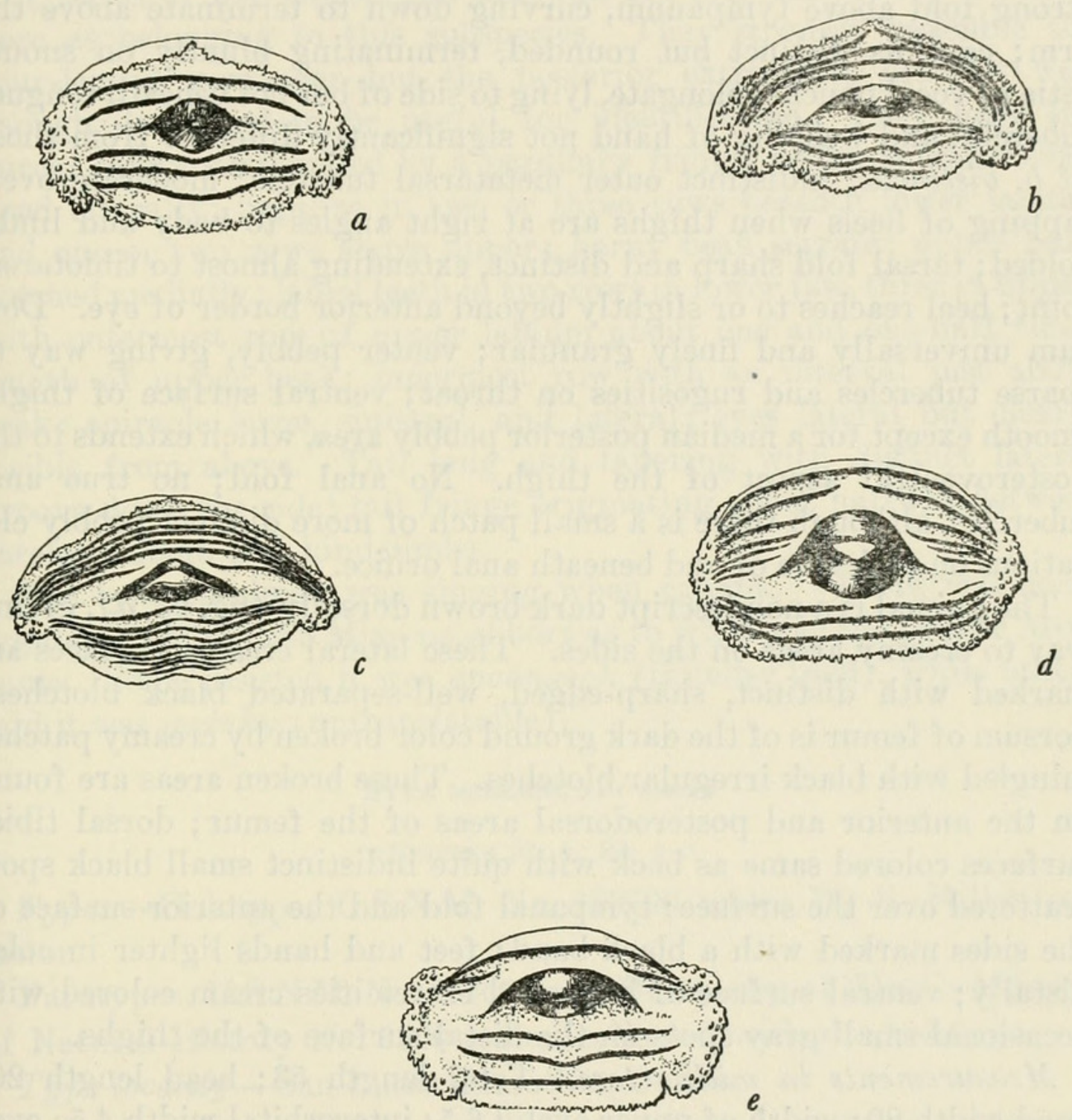

Figure 92.-a, Hyla bistincta labeculata, new subspecies; $b$, Hyla milleri, new species; $c, H y l a$ ? sp.; d, Hyla? sp.; e, Rana pipiens austricola. (All figures greatly magnified.) 
Collection data.-The specimen was singing in the river when it was collected at 9:10 p. m., April 29, 1946, by W. S. Miller.

Diagnosis.-A large Hyla (53 mm.) distinguished from $b$. bistincta by having the gray reticulation of the sides entirely broken up into elongate black blotches; tarsal fold moderately elevated.

Description.-Head as broad as long; nostril closer to tip of snout than eye; tympanum quite distinct and as wide as third finger pad; strong fold above tympanum, curving down to terminate above the arm; canthus distinct but rounded, terminating bluntly on snout; ostia of vocal pouches elongate, lying to side of but not beneath tongue; tubercles and webbing of hand not significantly different from those of $b$. bistincta; indistinct outer metatarsal tubercle; moderate overlapping of heels when thighs are at right angles to body and limbs folded; tarsal fold sharp and distinct, extending almost to tibiotarsal joint; heel reaches to or slightly beyond anterior border of eye. Dorsum universally and finely granular; venter pebbly, giving way to coarse tubercles and rugosities on throat; ventral surface of thighs smooth except for a median posterior pebbly area, which extends to the posteroventral aspect of the thigh. No anal fold; no true anal tubercles, although there is a small patch of more distinct pebbly elevations on each side of and beneath anal orifice.

The animal is a nondescript dark brown dorsally (fig. 93, $d$ ), giving way to creamy areas on the sides. These lateral creamy surfaces are marked with distinct, sharp-edged, well-separated black blotches; dorsum of femur is of the dark ground color broken by creamy patches mingled with black irregular blotches. These broken areas are found on the anterior and posterodorsal areas of the femur; dorsal tibial surfaces colored same as back with quite indistinct small black spots scattered over the surface; tympanal fold and the anterior surface of the sides marked with a black band; feet and hands lighter in color distally; ventral surface of body and extremities cream colored with occasional small gray spots on the distal surface of the thighs.

Measurements in millimeters.-Total length 53; head length 20; head width 20 ; width of upper eyelid 6.5 ; interorbital width 4.5 ; eyenostril 5.0 ; nostril-tip of snout 2.5 ; greatest diameter of tympanum 3.0 ; between nostrils 4.0 ; between choanae 6.0 ; width of third finger pad 3.0 ; width of fourth toe pad 2.0 ; length of tibia 28.5.

Remarks.-Miller says of the living specimen: "Reddish-brown back with tiny black spots' black and white spotted sides and rump."

Aside from the distinctive color pattern, there were no consistent anatomical differences apparent.

A tadpole of this species (U.S.N.M. No. 123690) was caught hopping on the bank half an hour before the type specimen was taken. It has a body length of 22 and a tail length of $21 \mathrm{~mm}$. Black spots are 
already distinct on the sides. It is similar to the adult except that a distinct (although quite small) outer metatarsal tubercle is present.

Two additional four-legged tadpoles (field No. F. 22) were taken on May 7 at 9 p. m. from stones jutting out of the stream. The black lateral spots are not so evident on them as they are on the one in the U. S. National Museum but they are present. Both possess small, distinct outer metatarsal tubercles.

A series of five two-legged tadpoles are also tentatively included here as belonging to this subspecies. They strongly resemble the four-legged specimens but the posterior extremities are not well enough developed to be useful for identification. They have the buccal cavity surrounded by a papillary fringe, which is well developed laterally; papillae in two or three rows beneath lower labium and one or two rows above upper; horny beak serrate; upper beak notched medially; labial teeth in two rows in lower jaw, three in upper, with outermost row of upper labium about one and one-half times length of upper beak; innermost row with an interval just above beak; spiracle large, sinistral, and lateral; eyes lateral but clearly visible from above. Tail long and tapering with distinct lateral groove down the side; tail fringe originating about halfway between foreleg anlage and hind limbs.

The type specimen was singing when caught. "There was some argument among the Mixe neighbors as to what was the proper Mixe name. Some insisted it was anaánooch (thunder toad), while others said it was wainky (untranslatable)."

HYLA MILLERI, new species

Figures $92, b ; 93, a-c$

Types.-Holotype, U.S.N.M. No. 123700 male; W. S. Miller collector.

Paratypes: U.S.N.M. No. 123699 and University of Illinois Museum of Natural History No. 3200 males, collected with the holotype.

Type locality.-San Lucas Camotlán, Oaxaca.

Collection data.-The specimens were collected on stones projecting from the river in the village. They were taken on the night of May 7 , 1946 , at $9: 10$ p. m.

Diagnosis.-A very small Hyla with granular eyelids; sharp canthi terminating bluntly on the snout; two vocal sacs present; subterminal articular tubercle of fourth finger divided; strong web between third and fourth fingers; outer palmar tubercle divided; glandular ridge from this tubercle to elbow; ventral surfaces of thighs strongly granular; throat with widespread scattered pustular protuberances; body uniformly dark tan above. 
Description.-Head as broad as or slightly broader than long; tympanum distinct, small, less than half the diameter of the eye; tympanum bordered above by an indistinct glandular fold that curves down behind the shoulder and is lost; canthi sharp and passing just inside the external nares, blunted on snout; nostrils closer to tip of snout than to eye; distance from nostril to eye equal to or slightly less than distance between nostrils.

Vomerine teeth prominent, divergent in an anterior direction, extending to or slightly beyond a line drawn between anterior borders of the choanae; tongue as broad as long and notched behind; vocal sacs open into narrow slits on each side of, just beneath edges of, and three-fourths of the way back of tongue.

Finger pads well developed, that of third digit as large as tympanum; prominent granular tubercle on thumb, lying parallel and just anterior to median palm tubercles (which also extend well onto base of thumb) ; lateral palmar tubercle divided, granular, and indistinct; second and fourth subarticular tubercles slightly larger than third; subterminal articular tubercle on outer finger bifid; supernumerary tubercles prominent on the second and third fingers; indistinct glandular ridge from outer palmar tubercle to the elbow; web between third and fourth fingers extends to the subterminal joint; strong definite web between the second and third fingers; slight webbing between first and second fingers; a marked ridge along lateral aspect of all fingers.

Three metatarsal tubercles present, medial many times larger than lateral; latter represented by a single small punctate elevation; intermediate tubercle indistinct, one-half size of median; foot almost completely webbed as shown in diagram; strong tarsal fold extending almost the length of tibia.

Eyelids of a rough granular appearance caused by many rounded glandular protuberances; entire top of head covered to a lesser extent by widely separated pustules; back with a leathery appearance under magnification, with occasional tiny pustules present; entire venter marked by strong pebbly elevation, especially on ventral surfaces of thighs; an indistinct transverse fold above the anus; no anal tuberosities.

Color.-Entire dorsum of specimen dark tan, the color lessening somewhat in intensity on the extremities; venter grayish yellow with indistinct small dark circular blotches on throat. Miller states that the frogs were light tan in life.

Measurements in millimeters. -Width of head 10; length of head 10 ; width of upper eyelid 4.0 ; interorbital space 4.3 ; width between nostrils 3.0 ; nostril to eye 3.0 ; width of tongue 7.0 ; length of tongue 6.8 to 7.0 ; distance between choanae 3.0 to 5.0 ; diameter of third 

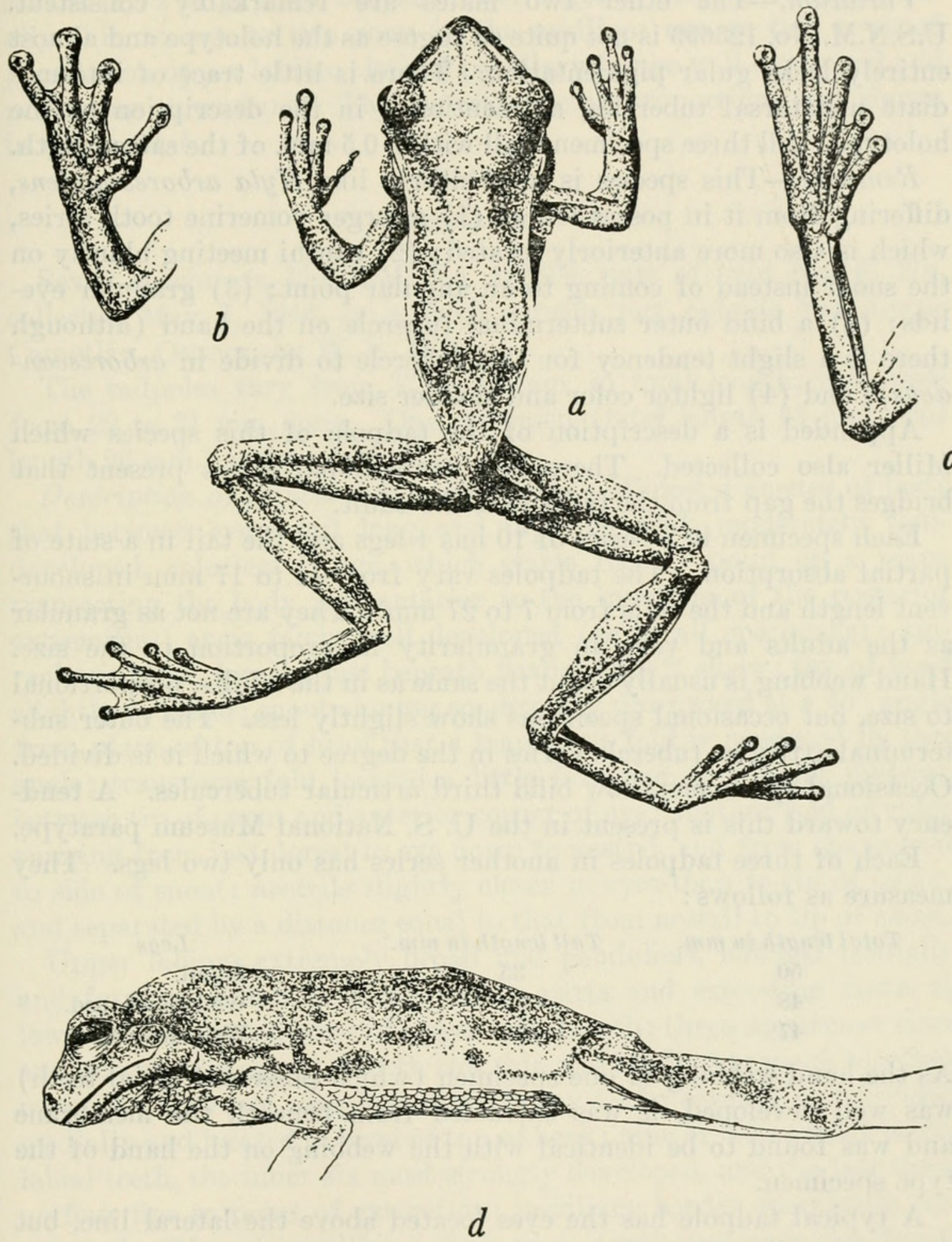

Figure 93.- $a-c$, Hyla milleri, new species : $a$, Specimen; $b$, hand ; $c$, foot; $d$, Hyla bistineta labeculata, new subspecies, holotype. 
finger pad 1.5; diameter of fourth toe pad 1.0; tibia 15.5; foot 12.0 ; total body length 30.5. The tibiotarsal joint reaches to between eye and nostril.

Variation.-The other two males are remarkably consistent. U.S.N.M. No. 123699 is not quite so rugose as the holotype and almost entirely lacks gular pigmentation. There is little trace of intermediate metatarsal tubercles, as mentioned in the description of the holotype. All three specimens fall within $0.5 \mathrm{~mm}$. of the same length.

Remarks.-This species is most nearly like Hyla arborescandens, differing from it in possession of (1) a larger vomerine tooth series, which is also more anteriorly located; (2) canthi meeting bluntly on the snout instead of coming to an angular point; (3) granular eyelids; (4) a bifid outer subterminal tubercle on the hand (although there is a slight tendency for this tubercle to divide in arborescamdens); and (4) lighter color and smaller size.

Appended is a description of the tadpole of this species which Miller also collected. There is a transitional series present that bridges the gap from the tadpole to the adult.

Each specimen in a series of 10 has 4 legs and the tail in a state of partial absorption. The tadpoles vary from 14 to $17 \mathrm{~mm}$. in snoutvent length and the tails from 7 to $27 \mathrm{~mm}$. They are not as granular as the adults and vary in granularity in proportion to the size. Hand webbing is usually about the same as in the adults, proportional - to size, but occasional specimens show slightly less. The outer subterminal articular tubercle varies in the degree to which it is divided. Occasional specimens show bifid third articular tubercules. A tendency toward this is present in the U. S. National Museum paratype.

Each of three tadpoles in another series has only two legs. They measure as follows:

Total length in $\mathrm{mm}$.

50

48

47
Tail length in $\mathrm{mm}$.

35

32

32

\author{
Legs \\ Small. \\ Well developed. \\ Well developed.
}

As the hand webbing of one specimen (which possessed labial teeth) was well developed, it was extracted from beneath the membrane and was found to be identical with the webbing on the hand of the type specimen.

A typical tadpole has the eyes located above the lateral line, but nearer this line than the middorsum; spiracle sinistral, somewhat closer to anus than to tip of snout; spiracle pointing upward and backward; anus dextral; tail insertion anterior to a transverse plane located at level of insertion of hind legs; caudal membrane translucent and flecked with brown dots; upper labium V-shaped and containing four rows of labial teeth, innermost row broken medially just above the horny beak; beak small, black, and serrate; five com- 
plete rows of lower labial teeth with evidences of a fragile row almost upon the papillary fringe; lower horny beak small and set well posterior to the upper; papillary fringe completely circumoral; several rows of papillae beneath lower edges of mouth, which gradually thin to one or two rows in the midline; one or two rows of papillae on upper labium; lateral papillary fringe well developed and projecting downward. The general buccal proportions are shown in figure $92, b$.

\section{HYLA？ sp.}

Figure 92, $c$

Seven specimens, U.S.N.M. No. 123694, part of field No. F. 17a, collected May 6, 1946, in a swift stream just outside San Lucas Camotlán, Oaxaca, by W. S. Miller.

The tadpoles vary from 37 to $47 \mathrm{~mm}$. in total length, with tails from 22 to $31 \mathrm{~mm}$. long. One specimen (total length $43 \mathrm{~mm}$., tail length $26 \mathrm{~mm}$.) is four-legged.

Description of typical two-legged form.-Widest diameter of body that between eyes; tail long and tapering with moderately welldeveloped, colorless fringe, which starts from a point on a plane transecting the body just anterior to the insertion of the posterior extremities; arms fairly well developed (as in all specimens); spiracle sinistral, located just beneath flexure of left elbow; top of head slightly rounded; snout sloping so abruptly downward at a $45^{\circ}$ angle from plane of top of head that a transverse fold is produced by this angle; transverse fold located a little posterior to a point midway between tip of snout and anterior corner of eye; another fold or ridge running from just dorsal to eye down to nostril, and from the nostril to side of snout; nostrils slightly closer to eyes than to tip of snout, and separated by a distance equal to that from nostril to tip of snout.

Upper labium extremely broad and pendulous, notched medially and forming a flap covering mouth parts and extending down to lower labium; seven rows of upper labial teeth; three uppermost rows and, to a certain extent, fourth row thin and tending to pinch together medially; six rows complete above horny beak; seventh row divided medially and located at level of top of beak; nine or ten rows of infralabial teeth, the inner six most strongly developed, and the last three or four fine to point of extinction; papillary border completely circumoral, although papillae reduce to a single row over the dorsal and ventral aspects of the labia.

Web between third and fourth fingers small, not reaching subterminal joints except as a thin fringe along the fingers, is distinct but slight between second and third fingers, faint between first and second fingers. 
Color uniform dark brownish black dorsally; tail marbled with brownish purple on a light tan background; abdomen smooth, light yellow-tan.

\section{HYLA? SP}

Figure 92, $d$

San Lucas Camotlán, Oaxaca, 29 tadpoles unnumbered except for field tags (part of F 15). Caught in the river in the flats below the town, on May 6, 1946.

A somewhat oval body shape with long, tapering, laterally grooved tail ; tail fin originating well posterior on dorsum just anterior to vertical plane of insertion of hind legs and terminating in a point; spiracle sinistral, eyes situated more dorsally than laterally; no lateral emargination of papillae; latter complete around lower labium, in only one row; papillary border barely overlapping outer edge of upper row of labial teeth; labial teeth in five well-developed rows with one and usually two tiny auxiliary rows on each side; outermost row of teeth complete above horny beak; second row slightly separated and remaining rows strongly separated by width of upper beak; three lower rows of labial teeth, the innermost row divided medially; upper horny beak only half or slightly more than half width of outermost upper row of labial teeth; both beaks serrate with lower deeply notched anteriorly.

Color dark brown dorsally, mottled with lighter brown on uppermost half of tail; dark color actually giving way to dark brown spots on a tan ground color as tail is approached; ventrally the tan giving way to yellow; tail fin speckled with brownish black dots; total lengths varying from 31 to $74 \mathrm{~mm}$.

As the smaller specimens appear to have differently shaped horny beaks, they were at first separated on this basis and on the basis of size. However, intermediate-sized specimens possess beaks intermediate in nature.

The river where the tadpoles were caught was swift flowing and had a stony bottom with sandy patches.

\section{Genus Rana Linnaeus}

\section{RANA PIPIENS AUSTRicola Cope}

Figure 92, $e$

R. [ana] h.[alecina] austricola Cope, Proc. Amer. Philos. Soc., vol. 23, p. 517, 1886.

Rana pipiens austricola Sмгтн, Journ. Washington Acad. Sci., vol. 37, p. 409, 1947.

U.S.N.M. No. 123697, from San Lucas Camotlán, Oaxaca. "Large greenish frog-caught in the river in the east edge of the village at about $6: 30$ p. m." 
Four tadpoles were procured from the same locality, which are here interpreted as belonging to this species. Two of them ( 45 and 39 $\mathrm{mm}$. total length) are badly dessicated. The larger of the other two is $58 \mathrm{~mm}$. in total length and $24 \mathrm{~mm}$. in body length. The caudal membrane starts anterior to the plane of insertion of the hind leg, although on one specimen the ridge extends forward from this hypothetical plane as far as the head; the membrane is large, translucent, and tapers to a point. The eyes are in the lateral plane of the body, although quite visible from above; spiracle lateral, sinistral, pointing up and back, situated closer to anus than snout; anus dextral.

Lateral papillary border of buccal cavity emarginate; upper papillary border extending to a point medial to lateral edge of outer tooth row; lower papillary border in a single row; three upper and three lower rows of labial teeth as shown in figure $92, e$; upper beak serrate; lower beak slightly serrate.

Color dark above, light below; grayish fine mottling on caudal membrane; intestinal spiral quite visible through abdominal wall.

If the author is correct in assigning these specimens to austricola, the third row of upper labial teeth becomes of possible taxonomic import.

"This frog is called tuk in Mixe, a name apparently applied to all frogs, although the tree inhabiters are considered by them to be toads and not frogs."

\section{RANA PIPIENS TRILOBATA Mocquard}

Rana trilobata Mocquard, Bull. Soc. Philom. Paris, ser 9, vol. 1, p. 158, pl. 1, fig.

1, 1899. (Jalisco, Mexico.)

Rana pipiens trilobata Sмгтн, Journ. Washington Acad. Sci., vol. 37, p. 409, 1947.

U.S.N.M. Nos. 123577 to 123579 , four specimens, from El Salto, Durango, Ralph G. Miller collector.

Smith (1947) revived the names austricola and trilobata for subspecies of Rana pipiens from the southern Atlantic coastal areas and the plateau of Mexico, respectively. His description, however, did not include a diagnosis. As the two subspecies are strikingly distinct, the following tabulation is submitted for purposes of bringing out this contrast. Reservations toward the data should be held because of the small number of specimens involved.

\section{trilobata}

Posterior surface of thighs very granular.

Long, strong, raised dorsal glandular ridges with prominent pustules between them.

Heels not or barely overlapping. Head slightly longer than wide.

\section{austricola}

Posterior surface of thighs comparatively smooth.

Glandular ridges low, pustules indistinct or absent.

Heels strongly overlapping

Head slightly wider than long. 


\section{Genus ANOLIS Daudin}

\section{ANOLIS LIOGASTER Boulenger}

Anolis liogaster Boulenger, Proc. Zool. Soc. London, vol. 2, p. 245, pl. 6, fig. $2,1905$.

U.S.N.M. Nos. 477748 female, 47749 male, 47750 female, 47751 male, 47752 female, from Omilteme, Guerrero, all collected by Nelson and Goldman.

These specimens are of some interest as they include the only males reported since the single male included in Boulenger's type description. Boulenger states: "The male is remarkable in the absence of the inner digit on the four limbs." His specimen may be regarded as an anomaly, as the two males collected by Nelson and Goldman have the normal quota of five digits on each extremity.

The supraorbital semicircles may touch or be separated by a median row of scales. Supraoculars are three in number but occasional smaller scales may split off from any of the three plates.

\section{ANOLIS PETERSII Bocourt}

Anolis petersii Bocourt, Mission scientifique au Mexique. Études sur les reptiles, livr. 2 , pp. 79, 80, pl. 13, fig. 2 ; pl. 15, figs. 11, 11a, 1873.

U.S.N.M. No. 12244, three specimens, from Mirador, collected by Dr. Sartorius.

\section{ANOLIS SERICEUS Hallowell}

Anolis sericeus Hallowell, Proc. Acad. Nat. Sci. Philadelphia, vol. 8, pp. 227$228,1856$.

U.S.N.M. Nos. 123703 female, and 123704 male, from Cacalotepec, Oaxaca, collected by W. S. Miller; U.S.N.M. No. 47391, from San Miguel Albarradas, Oaxaca, collected by Nelson and Goldman.

Miller states that the male was light tan above with white arrowlike markings, edged in dark brown with apices pointed toward the tail. These are lateral in distribution. He says of the dewlap: "A distensible bladelike skin pouch. As the lizard sat sunning itself it would recurrently distend this fan. The effect was startling. The sun shining through the distended thin skin made even more marked the contrast between the reddish salmon color of the throat sack and the over-all color of the animal." There is a purplish spot on the posterior portion of the dewlap, as is characteristic of the species.

Miller says that the female in life had a light magenta line on a dark brown ground color. 


\section{Genus SCELOPORUS Wiegmann}

\section{SCELOPORUS SCALARIS SCALARIS Wiegmann}

Sceloporus scalaris Wiegmann, Isis von Oken, vol. 21, p. 370, 1828.

Sceloporus scalaris scalaris Sмгтн, Occ. Pap. Mus. Zool. Univ. Michigan, No. 361 , pp. 2, 3, 1937.

U.S.N.M. No. 123582, from El Salto, Durango, collected by Ralph G. Miller.

Varies from the normal in that the specimen has the blue spot on the anterior portion of the black shoulder marking instead of in the middle of this spot. Also the tibia is only about 85 percent of the length of the head, instead of the customary 90 percent or more. There are two canthals.

\section{SCELOPORUS SPINOSUS CAERULEOPUNCTATUS Smith}

Sceloporus spinosus caeruleopunctatus Sмітн, Kansas Univ. Sci. Bull., vol. 24, pp. 469-473 (1936), 1938.

U.S.N.M. No. 123706 female, from near Santa Maria Albarradas, Oaxaca, collected by W. S. Miller on May 22, 1946.

Dorsal scale rows 30 (31 or more in 90.7 percent) ; femoral pores $9-9$ (10 or more in 87.4 percent). Smith $(1939$, p. 98$)$ points out that other specimens from Oaxaca show these low counts. However, as his specimens are from over 50 miles south of Santa María Albarradas, and as the zone of intergradation between s. spinosus and s. caeruleopunctatus is near Albarradas, the low counts of Miller's specimens may best be explained as evidence of intergradation with the former.

The Mixe name for the lizard is chintete.

\section{Genus XENOSAURUS Peters}

\section{XENOSAURUS GRANDIS (Gray)}

Cubina grandis GraY, Ann. Mag. Nat. Hist., ser. 2, vol. 18, p. 270, 1856.

Xenosaurus grandis Cope, Proc. Acad. Nat. Sci. Philadelphia, vol. 18, p. 322, 1866.

U.S.N.M. No. 123705, from San Lucas Camotlán, Oaxaca, at 8:00 a. m., April 14, 1946.

Miller states that the lizard lives in cracks in large rocks. During the day it may be seen resting here with only the head protruding. The specimen caught was in the act of shedding its skin. It was located on the shady side of a rock cliff just a short way from a crevice. The Mixe name is puknem.

The living specimen, according to Miller, had an orange eye with a black pupil. The head and neck were spotted with light tan spots, and two light $\tan \mathbf{V}$-shaped marks. The body bands were likewise of this light tan, although they gradually darkened to a dark tan on the tail. The gular region was light salmon, and the abdomen brown with black-splotched irregular bands. 


\section{Genus NINIA Baird and Girard}

\section{NINIA SEBAE SEBAE (Duméril, Bibron, and Duméril)}

Streptophorus sabae Duméril, Bibron, and Duméril, Erpetologie générale, vol. 7, pt. 1, 515, 1854.

Ninia sebae sebae Schmidt and Andrews, Publ. Field Mus. Nat. Hist., zool. ser., vol. 20 , p. $170,1936$.

U.S.N.M. Nos. 123711 male, and 123710 female, from San Lucas Camotlán, Oaxaca. The female was taken at 8:00 p. m. on a big rock extending into the river in the center of town. The male was caught 20 minutes later within a few feet of where the female was taken.

There are 19 scale rows in both specimens. Male ventrals 151, caudals 50 ; female ventrals 147 , caudals 52 . The male ventrals are high in number for the subspecies, as they are usually less than 140 .

Ground color of the living specimens was red with contrasting black bands.

\section{Genus TANTILLA Baird and Girard}

\section{TANTILLA PHRENITICA Smith}

Tantilla phrenitica SмIтH, Zoologica, vol. 27, p. 39, 1942.

U.S.N.M. No. 123707 female, from Oaxaca, taken on trail just west of Camotlán at 5: 30 p. m. "T.he day had been hot, but it now clouded over and began to thunder, threatening rain."

Total length $280 \mathrm{~mm}$; tail $46 \mathrm{~mm}$.; scales in 15 rows; ventrals 146 ; caudals 36 ; mental contacts chin shields.

The specimen was black above, salmon colored below. A fleshcolored band crosses the back of the head involving the tips of the parietals.

\section{Genus THAMNOPHIS Fitzinger}

\section{THAMNOPHIS CHRYSOCEPHALUS (Cope)}

Eutaenia chrysocephalus Cope, Proc. Amer. Philos. Soc., vol. 22 1884, pp. 173, $174,1885$.

Thamnophis chrysocephalus Sмгтн, Zoologica, vol. 27, p. 104, 1942.

U.S.N.M. No. 123708 male, from San Lucas Camotlán, Oaxaca, taken April 16, 1946, in right-hand fork of the river located in the west end of the town.

Miller writes of this specimen: "Over-all color dark brown with black spots. Dorsal line light greenish brown near head, becoming darker farther back of the anus. Belly a bluish gray. On sides a very light tan stripe runs from base of jaws to just back of anus where it almost disappears, blending into belly." Mr. Miller's description is accompanied by a sketch, demonstrating the distinct nature of the 
stripe. Unfortunately the single specimen obtained has suffered dehydration at one time or another, and while it has been beautifully restored with trisodium phosphate, the lateral stripes can barely be made out. The dorsal stripe can be noted only by considerable manipulating and a maximum of wishful thinking. As a matter of fact, the dark spots between the stripes can hardly be distinguished. The anterior dozen ventrals show much more black pigmentation than is common for this species.

Though a dorsal stripe on the back of chrysocephatus may eventually prove to be of subspecific value, it is obvious that no reliable diagnosis may now be attempted on the basis of a single dehydrated specimen. The specimen does occur on the southeastern edge of the known range for the species, and other striped specimens may be found to the south and east and possibly to the south and west nearer the coast. In fact, Smith (1942) records such a specimen, EHT-HMS 23778, from Omilteme, Guerrero, which has a light stripe on the middorsal row of scales fading out about an inch behind the head; two others in the British Museum of Natural History, from Omilteme, Guerrero, and Jalapa, Veracruz, are similar (fide Smith, in conversation).

\section{Genus BOTHROPS Wagler}

\section{BOTHROPS NUMMIFER VERAECRUCIS Burger}

Bothrops nummifer veraecrucis BurGer, Bull. Chicago Acad. Sci., vol. 9, pp. 59-67, pl. 1, fig. 1, 1950.

U.S.N.M. Nos. 123709 male, and 123712 female, from 4 miles south of San Lucas Camotlán, Oaxaca.

Both specimens were taken while sunning in a chili patch 4 miles from the town. The eyes of the male were a bright golden-flecked color in life. The pupil was narrowed "to a mere pin point of black." There were beautiful dark brown markings on a lighter brown ground color. In most instances the dark brown marks were separated by a faint whitish edging.

Two field mice were extracted from the male.

The Mixe name for the snake is puhk.

\section{LITERATURE CITED}

Boulenger, G. A.

1905. Description of new reptiles discovered in Mexico by Dr. H. Gadow. Proc. Zool. Soc. London, vol. 2, pp. 245-247, 2 pls.

Breder, C. M.

1946. Amphibians and reptiles of the Río Chucunaque drainage, Darién, Panama, with notes on their life histories and habits. Bull. Amer. Mus. Nat. Hist., vol. 86, art. 8, pp. 381-435, 25 figs., 19 pls. 
KeLlOGg, ReMington.

1932. Mexican tailless amphibians in the United States National Museum. U. S. Nat. Mus. Bull. 160, 223 pp., 24 figs., 1 pl.

OWEN, Richand.

1844. Characters of a new species of axolotl. Ann. Mag. Nat. Hist., ser. 1, vol. 14 , p. 23,1 fig.

SмiтH, H. M.

1939. The Mexican and Central American lizards of the genus Sceloporus. Publ. Field Mus. Nat. Hist., zool. ser., vol. 26, 395 pp., 31 pls., 59 figs.

1942. The synonymy of the garter snakes (Thamnophis), with notes on Mexican and Central American species. Zoologica, vol. 27, pp. 97-123.

1947. Notes on Mexican amphibians and reptiles. Journ. Washington Acad. Sci., vol. 37, pp. 408-412.

SMith, H. M., and TAYLOR, E. H.

1945. An annotated checklist and key to the snakes of Mexico. U. S. Nat. Mus. Bull. 187, 239 pp.

1948. An annotated checklist and key to the Amphibia of Mexico. U. S. Nat. Mus. Bull. 194, 118 pp.

Stuart, L. C.

1948. The amphibians and reptiles of Alta Verapaz, Guatemala. Misc. Publ. Mus. Zool., Univ. Michigan, No. 69, pp. 5-109, 10 figs.

TAYLOR, E. H.

1939. New species of Mexican tailless Amphibia. Univ. Kansas Sci. Bull., vol. 25, 1938, pp. 385-405, 2 figs., 3 pls.

1941. Two new ambystomid salamanders from Chihuahua. Copeia, vol. 3 , pp. 143-146, 2 figs.

1942. Tadpoles of Mexican Anura. Univ. Kansas Sci. Bull., vol. 28, pt. 1, pp. 37-55, 3 pls.

Wright, A. H.

1929. Synopsis and description of North American tadpoles. Proc. U. S. Nat. Mus., vol. 74, art. 11,70 pp., 9 pls. 


\section{$2 \mathrm{BHL}$ Biodiversity Heritage Library}

Shannon, F A. 1951. "Notes on a herpetological collection from Oaxaca and other localities in Mexico." Proceedings of the United States National Museum 101(3284), 465-484. https://doi.org/10.5479/si.00963801.101-3284.465.

View This Item Online: https://www.biodiversitylibrary.org/item/31795

DOI: https://doi.org/10.5479/si.00963801.101-3284.465

Permalink: https://www.biodiversitylibrary.org/partpdf/30783

\section{Holding Institution}

Smithsonian Libraries

\section{Sponsored by}

Smithsonian

\section{Copyright \& Reuse}

Copyright Status: NOT_IN_COPYRIGHT

Rights: https://www.biodiversitylibrary.org/permissions/

This document was created from content at the Biodiversity Heritage Library, the world's largest open access digital library for biodiversity literature and archives. Visit BHL at https://www.biodiversitylibrary.org. 